\title{
ANALISIS KETERAMPILAN MENULIS EKSPOSISI KELAS 5 SD NEGRI DURI KEPA JAKARTA
}

\author{
Nur Latifah', Najib Hasan ${ }^{2}$ \\ Universitas Muhammadiyah Tangerang \\ nurlatifah1v4@gmail.com
}

\begin{abstract}
ABSTRAK
Penelitian ini bertujuan untuk mendeskrifsikan kelogisan, penyusunan, penggunana tata bahasa, kosa kata dan ketepataan ejaan penulisan karangan ekposisi siswa kelas 5 SDN Duri Kepa, Jakarta. Penelitian ini mengunakan metode deskriptif kualitatif. Hasil dari penelitian ini adalah (1) kelogisan dan kesistematisan karangan merupakan ide kalimat yang di terima oleh akal dan penulisannya sesuai dengan ejaan. (2) penyusunan organisasi karangan merupakan pengelompokan gambar atau kejadian suatu "peristiwa" secara tersusun untuk di jadikan sebuah cerita. (3) penggunana tata bahasa merupakan penggunaan kata di setiap baris atau kalimat dengan penulisan yang dibicarakan atau yang di gambarkan dari sebuah peritiwa dengan benar. (4) kosa kata merupakan kata yang di gunakaan secara baku atau tidak baku di dalam penulisan kalimat di dalam penulisannya. (5) ketepataan ejaan merupakan penempatatan atau menggambarkan perhentian antara perhetian akhir, tekanan, tanda tanya dan lainnya.
\end{abstract}

Kata Kunci: karangan ekposisi, keterampilan menulis

\section{A. PEndahuluan}

Menulis merupakan suatu bentuk komunikasi berbahasa (verbal) yang menggunakan simbol-simbol tulisan sebagai mediannya. Menulis merupakan kegiatan dalam proses belajar megajar mengenai kemampuan dan potensi diri kita sampai di mana pengetahuan kita tentang topik atau materi yang di berikan. Dalam menulis, untuk dapat mencapainya diperlukan suatu pengetahuan dan potensi, terhadap kemampuan yang di miliki setiap orang untuk memberikan suatu topik dari materi yang di berikan.

Kompleksitas keterampilan menulis terletak pada tuntutan kemampuan untuk menata dan mengorganisasikan ide, pemikiran, pengetahuan dan pengalaman secara runtun dan logis serta menyajikan ragam bahasa tulis dan kaidah penulisan lainnya. Keterampilan menulis merupakan sebagai tuntutan bagi setiap orang untuk menata dan mengorganisasikannya ke dalam suatu ide, pemikiran, pengatahuan dan pengalaman yang di tuliskan secara runtun serta logis. Karangan eksposisi dapat dianalisis dari berbagai sudut yaitu: kelogisan, penyusunan, penggunana tata bahasa, kosa kata dan ketepataan ejaan. 
Menurut Dalman (2015:119) Eksposisi merupakan salah satu jenis karangan yang harus di perkenalkan kepada siswa dan di kuasai oleh seorang guru mata pelajaran bahasa Indonesia. Eksposisi adalah suatu paragraf yang memiliki tujuan untuk memperjelas informasi yang saat itu terjadi serta menerangkannya kedalam suatu pengetahuan untuk mengajak serta mendesak seseorang untuk dapat membaca serta menerima apa yang terjadi di dalam suatu tulisan dari topik pembasan ataupun buku.

Keterampilan menulis eksposisi berkaitan dengan (1) Kelogisan dan kesistematisan karangan merupakan ide kalimat yang di terima oleh akal dan penulisannya sesuai dengan ejaan. (2) Penyusunan organisasi karangan merupakan pengelompokan gambar atau kejadian suatu "peristiwa" secara tersusun untuk di jadikan sebuah cerita. (3) Penggunana tata bahasa merupakan penggunaan kata di setiap baris atau kalimat dengan penulisan yang dibicarakan atau yang di gambarkan dari sebuah peritiwa dengan benar. (4) Kosa kata merupakan kata yang di gunakaan secara baku atau tidak baku di dalam penulisan kalimat di dalam penulisannya. (5) Ketepataan ejaan merupakan penempatatan atau menggambarkan perhentian antara perhetian akhir, tekanan, tanda tanya dan lainnya.

Berdasarkan Standar kompetensi yang ada di kelas 3 semester 2 Sekolah Dasar, menulis karangan sederhana menjadi salah satu yang di ajarkan si sekolah. Siswa kelas 5 SD rata-rata berusia 11-12 tahun, menurut piaget pada usia ini anak berada pada fase oprasional kongkrit. Pada tahapan ini anak sudah cukup matang menggunakan pemikiran logika atau operasi. Adapun tujuan penelitian ini adalah mendeskrifsikan karangan ekposisi siswa kelas 5 SDN Duri Kepa, Jakarta. Deskripsi yang di maksud meliputi kelogisan, penyusunan, penggunana tata bahasa, kosa kata dan ketepataan ejaan penulisan. Tujuan penelitian ini yaitu untuk mendeskripsikan kelogisan, penyusunan, penggunana tata bahasa, kosa kata dan ketepataan ejaan penulisan karangan ekposisi siswa kelas 5 SDN Duri Kepa, Jakarta.

\section{B. KAJIAN PUSTAKA}

Keterampilan merupakan kualitas proses dari pekerjaan atau kegiatan yang dilakukan oleh mereka yang memiliki pengetahuan dan menggunakan pengetahuan itu untuk menanggani masalah atau situasi baru (Saleh, 2013:26 ). Keterampilan sebagai suatu pekerjaan yang dapat di lakukan kedalam suatu pengetahuan serta menanggani masalah dari kegiatan yang di lakukan terhadap keterampilan yang di miliki setiap orang. Sehingga, keterampilan sebagai penggetahuan yang di dapat untuk hal yang baru serta menyampaikan suatu pesan sebagai 
Lingua Rima: Jurnal Pendidikan Bahasa dan Sastra Indonesia

Vol. 9 No. 2 Juli 2020

kegiataan atau pekerjaan.

Menulis merupakan bagian yang tidak terpisahkan dalam seluruh proses belajar yang di alami peserta didik didik serta mengenali kemampuan dan potensi diri kita sampai di mana pengetahuan kita tentang topik atau materi yang diberikan (Akhdiah, 2016: 1). Menulis merupakan bagian yang tidak dapat terpisahkan di dalam proses belajar. Sehingga untuk dapat mencapainya di perlukan suatu pengetahuan dan potensi, terhadap kemampuan yang di miliki setiap orang untuk memberikan suatu topik dari materi yang diberikan.

Sedangkan Yunus (2013:19) mengatakan bahwa keterampilan menulis merupakan kegiatan yang kompleks, kompleksitas menulis terletak pada tuntutan kemampuan untuk menata dan mengorganisasikan ide, pemikiran, pengetahuan dan pengalaman secara runtun dan logis serta menyajikan ragam bahasa tulis dan kaidah penulisan lainnya. Keterampilan sebagai tuntutan bagi setiap orang untuk menata dan mengorganisasikannya ke dalam suatu ide, pemikiran, pengatahuan dan pengalaman yang di tuliskan secara runtun serta logis.

Eksposisi merupakan salah satu jenis karangan yang harus di perkenalkan kepada siswa dan di kuasai oleh seorang guru mata pelajaran Bahasa Indonesia. Menurut Finoza (2013:264) Eksposisi merupakan wancana yang bertujuan untuk memberi tahu, mengupas, menguraikan, atau menerangkan sesuatu berupa informasi yang kita baca sehari - hari di dalam media massa serta di paparkan dengan tujuan memperluas pandangan dan pengetahuan pembaca. Eksposisi sebagai suatu tujuan yang memiliki wancana di dalam topik serta informasi yang didapat melalui media massa. untuk mengupas, menguraikan serta menerangkan dari apa yang di lakukannya kedalam kehidupan sehari - hari untuk memperluas pengetahuan.

Analisis karangan ekposisi dalam penelitian ini difokuskan pada kelogisan, penyusunan, penggunana tata bahasa, kosa kata dan ketepataan ejaan penulisan. Kelogisan dan kesistematisan karangan merupakan ide kalimat yang di terima oleh akal dan penulisannya sesuai dengan ejaan. Penyusunan organisasi karangan merupakan pengelompokan gambar atau kejadian suatu "peristiwa" secara tersusun untuk di jadikan sebuah cerita. Penggunana tata bahasa merupakan penggunaan kata di setiap baris atau kalimat dengan penulisan yang dibicarakan atau yang di gambarkan dari sebuah peritiwa dengan benar. Kosa kata merupakan kata yang di gunakaan secara baku atau tidak baku di dalam penulisan kalimat di dalam penulisannya. Ketepataan ejaan merupakan penempatatan atau menggambarkan perhentian antara perhetian akhir, tekanan, tanda tanya dan lainnya dengan kriteria rubrik yang berbeda- 
Lingua Rima: Jurnal Pendidikan Bahasa dan Sastra Indonesia

Vol. 9 No. 2 Juli 2020

beda (2015: 242-243).

\section{METODE PENELITIAN}

Penelitian ini menggunakan metode deskriptif kualitatif. Penelitian deskriptif digunakan karena penelitian ini berusaha mendeskripsikan karangan eksposisi siswa kelas V SDN Duri Kepa 06 Pagi, Jakarta tahun pelajaran 2017/2018, pendekatan kualitatif ini merupakan prosedur penelitian yang menghasilkan data deskriptif kualitatif berupa kata-kata tertulis atau lisan dari orang-orang dan prilaku yang di amati (Prastowo2012: 22).

Peneliti berkedudukan sebagai instrumen yang berperan sebagai pengumpul data, penganalisis data, dan pelapor hasil penelitian. Peneliti menggunakan tes tulis untuk mengumpulkan data. Instrumen utama penelitian ini adalah lembar kerja siswa yang divalidasi oleh pakar. Data yang diperoleh berupa data verbal, yaitu berupa karangan argumentasi siswa yang diklasifikasikan berdasarkan aspek yang diteliti, sedangkan sumber data berupa karangan argumentasi siswa kelas V SDN Duri Kepa 06 Pagi, Jakarta yang berjumlah siswa yang berasal dari dua kelas yang berbeda. Teknik pengumpulan data dengan tes menulis. Siswa diberi tugas untuk menulis karangan Eksposisi berdasarkan tema yang telah ditentukan peneliti dan diberi Lembar Kerja Siswa. Di dalamnya terdapat panduan untuk mengerjakan tugas, kemudian hasil tulisan siswa didokumentasikan dan dianalisis sesuai rumusan masalah.

Data yang diperoleh dianalisis dengan cara berikut: membaca karangan, menyederhanakan data karangan sesuai dengan aspek yang diteliti, memberikan kode, mengkategorikan, mendeskripsikan, dan mengidentifikasi data, membuat korpus data, dan yang terakhir adalah menyajikan data. Pengecekan keabsahan data dilakukan dengan ahli dan menggunakan bahan referensi sebagai data pendukung

\section{HASIL PENELITIAN}

Adapun penilaian untuk Kelogisan dan kesistematisan karangan merupakan ide kalimat yang di terima oleh akal dan penulisannya sesuai dengan ejaan. Mengunakan rubrik penilaian dengan keriteria Sangat baik :Bermakna, menarik, tepat, jalan pikiran, baik dan relevan dengan topik. Baik: Pada umumnya baik, tetapi faktanya tidak berkembang sehingga terjadi banyak pengulangan. Cukup: Pengembangan kurang relevan dengan isi. Kurang: Tidak tampak usaha membuat karangan bermakna atau tidak relevan dengan judul yang di minati.

Penyusunan organisasi karangan merupakan pengelompokan gambar atau kejadian suatu 
"peristiwa" secara tersusun untuk di jadikan sebuah cerita. Memiliki rubrik penilaian dengan keriteri Sangat baik: Paragraf tersusun rapi, pemakaian kalimat topik baik, organisai menyakinkan, alur karangan mudah di ikuti. Baik: Fakta tersusun dalam paragraf dengan baik, tetapi agak terbeli-belit. Cukup: Ada usaha menyusun paragraf dengan baik, tetapi batas ide pada setiap paragraf tidak jelas. Kurang: Urutan paragraf sulit di ikuti, sulit di pahami, atau paragraf tidak terencana.

Penggunana tata bahasa merupakan penggunaan kata di setiap baris atau kalimat dengan penulisan yang dibicarakan atau yang di gambarkan dari sebuah peritiwa dengan benar. Rubrik penilaian dengan keriteria Sangat baik: Kalimat lancar, cermat, meskipun sedikit ada kesalahan tata bahasa. Baik: Kalimat ancar, cermat, tetapi ada kesalahan tata bahasa menyebabkan menjadi rancu. Cukup: Ada kesalahan tata bahasa yang cukup prinsip menyebabkan kalimat tidak gramatikal. Kurang: Pemakaian kata tidak tepat, menyebabkan kalimat sulit di pahami dan bentuk kata semua salah atau tidak memadai untuk di evaluasi.

Kosa kata merupakan kata yang di gunakaan secara baku atau tidak baku di dalam penulisan kalimat di dalam penulisannya. Keriteria rubrik sebagai berikut Sangat baik: Pemakaian kata lancar, tepat, tidak bermakna ganda. Baik: Makna kata jelas, tetapi kurang tepat penggunannya. Cukup: Makna kata kurang jelas, dan kurang tepat penggunannya, banyak kata yang bermakna ganda. Kurang: Pemakaian kata tidak tepat, menyebabkan kalimat sulit di pahami dan bentuk kata semua salah atau tidak memadai untuk di evaluasi.

Ketepataan ejaan merupakan penempatatan atau menggambarkan perhentian antara perhetian akhir, tekanan, tanda tanya dan lainnya. Memiliki keriteria penilaian sebagai berikut Sangat baik: Pemakaian ejaan dan tanda baca baik sekali, penulisan kata baik, penulisan huruf, penulisan kata depan, dan penggunaan suku kata semuanya benar. Baik: Ada kesalahan ejaan dan tanda baca. Cukup: Banyak kesalahan ejaan dan tanda baca, tetapi masih dapat di pahami. Kurang:

Kesalahan ejaan dan tanda baca banyak sekali atau penggunaan ejaan dan tanda baca serba salah

\section{KELOGISAN}

Kelogisan dan kesistematisan karangan merupakan ide kalimat yang di terima oleh akal dan penulisannya sesuai dengan ejaan.Kebanyakan siswa masih mengembangkan pemahaman secara umun dan terjadi banyak pengulanagn kata-kata dalam karangan. Sehingga nilai yang di 
dapat masuk dalam kriteria baik. Pengembanagn yang siswa miliki masih kurang relevan dengan isi. Contohnnya ada beberapa siswa yang mengemukakan pendapat yang rancu sehingga sulit di pahami pembaca. Bahkan untuk beberapa siswa tidak tampek usaha membuat karangan bermakna atau tidak relevan dengan judul yang di minati.

Berdasarkan hasil penelitian Menulis Karangan Eksposisi,maka dapat di ketahui bahwa Kerampilan Menulis Eksposisi pada kriteria kelogisan siswa kelas 5 SD Duri Kepa 06 Pagi, Jakarta masih terbilang rendah. Sesuai dengan Dengan perhitungan yang di jumlahkan dari seluruh kelas 5 hanya 22,96 \% siswa yang mendapat nilai di atas nilai KKM dan rata-rata siswa mendapat nilai 6,43 .

\section{PENYUSUNAN}

Penyusunan organisasi karangan merupakan pengelompokan gambar atau kejadian suatu "peristiwa" secara tersusun untuk di jadikan sebuah cerita.Berdasarkan analisis yang ada masih banyak siswa yang membuat urutan paragraf sulit di ikuti, sulit di pahami, atau paragraf tidak terencana. Tetapi setengah dari jumlah siswa sudah memiliki usaha umtuk menyusun paragraf dengan baik, tetapi batas ide pada setiap paragraf tidak jelas. Dan sangat jangan siswa yang membuat paragraf tersusun rapi, pemakaian kalimat topik baik, organisai menyakinkan, alur karangan mudah di ikuti.

Berdasarkan hasil penelitian Menulis Karangan Eksposisi,maka dapat di ketahui bahwa Kerampilan Menulis Eksposisi pada kriteria Penyusunan siswa kelas 5 SD Duri Kepa 06 Pagi, Jakarta masih terbilang rendah. Sesuai dengan Dengan perhitungan yang di jumlahkan dari seluruh kelas 5 hanya18,5 \% siswa yang mendapat nilai di atas nilai KKM dan rata-rata siswa mendapat nilai 5,18 .

\section{PENGGUNAAN TATA BAHASA}

Penggunana tata bahasa merupakan penggunaan kata di setiap baris atau kalimat dengan penulisan yang dibicarakan atau yang di gambarkan dari sebuah peritiwa dengan benar. Sedikit sekali siswa yang membuat kalimat lancar, cermat, meskipun sedikit ada kesalahan tata bahasa. Sedangkan point yang terdapat banyak kekurangan adalah pemakaian kata tidak tepat, menyebabkan kalimat sulit di pahami dan bentuk kata semua salah atau tidak memadai untuk di evaluasi.

Berdasarkan hasil penelitian Menulis Karangan Eksposisi,maka dapat di ketahui bahwa Kerampilan Menulis Eksposisi pada kriteria Penggunaan tata bahasa siswa kelas 5 SD Duri 
Kepa 06 Pagi, Jakarta masih terbilang rendah. Sesuai dengan Dengan perhitungan yang di jumlahkan dari seluruh kelas 5 hanya14,15 \% \% siswa yang mendapat nilai di atas nilai KKM dan rata-rata siswa mendapat nilai 3,96.

\section{KOSA KATA}

Kosa kata merupakan kata yang di gunakaan secara baku atau tidak baku di dalam penulisan kalimat di dalam penulisannya. Berdasarkan analisis setengah dari jumlah siswa kurang dalam Pemakaian kata tidak tepat, menyebabkan kalimat sulit di pahami dan bentuk kata semua salah atau tidak memadai untuk di evaluasi. Dan sedikit sekali pemakaian kata lancar, tepat, tidak bermakna ganda.

Berdasarkan hasil penelitian Menulis Karangan Eksposisi,maka dapat di ketahui bahwa Kerampilan Menulis Eksposisi pada kriteria kosa kata siswa kelas 5 SD Duri Kepa 06 Pagi, Jakarta masih terbilang rendah. Sesuai dengan Dengan perhitungan yang di jumlahkan dari seluruh kelas 5 hanya13,03 \% siswa yang mendapat nilai di atas nilai KKM dan rata-rata siswa mendapat nilai 3,65.

\section{KETEPATAN EJAAN PENULISAN}

Ketepataan ejaan merupakan penempatatan atau menggambarkan perhentian antara perhetian akhir, tekanan, tanda tanya dan lainnya.Sesuai analisis sudah banyak siswa yang mengunakan ejaan dan tanda baca baik sekali, penulisan kata baik, penulisan huruf, penulisan kata depan, dan penggunaan suku kata semuanya benar. Dan memliki kesalahan ejaan dan tanda baca yang sedikit

Berdasarkan hasil penelitian Menulis Karangan Eksposisi,maka dapat di ketahui bahwa Kerampilan Menulis Eksposisi pada kriteria ketepatan ejaan penulisan siswa kelas 5 SD Duri Kepa 06 Pagi, Jakarta masih terbilang rendah. Sesuai dengan Dengan perhitungan yang di jumlahkan dari seluruh kelas 5 hanya3,03 \% siswa yang mendapat nilai di atas nilai KKM dan rata-rata siswa mendapat nilai 8,50 .

\section{E. KESIMPULAN}

Berdasarkan hasil analisis keterampilan menulis eksposisi siswa kelas 5 SD Negeri Duri Kepa 06 Pagi Jakarta. Di dapati aspek kriteria tertinggi yang di pahami adalah Ketepatan ejaan setelah itu keriteria kosa kata, pengunaan tata bahasa dan aspek kriteria menulis akposisi yang paling rendah adalah kelogisan. Hal ini di karnakan kurangnnya bacaan siswa sehingga ketika di minta untuk membuat karangan hanya kalimat-kalimat sesuai pemahaman yang ada saja 
yang di kemukakan. Faktor-faktor yang memengaruhi keterampilan menulis eksposisi siswa kelas 5 sangat beragam, yaitu penulisan yang kurang jelas, kurangnya latihan menulis, berhenti di paragraf atau tengah kalimat, tidak adanya peran guru serta keluarga dan tidak memahami isi penulisan secara perlahan di dalam menulis karangan.

\section{F. DAFTARPUSTAKA}

Akhadiah, Sabarti. (2016). Pembinaan Kemampuan Menulis Bahasa Indonesia. Jakarta: PT. Gelora Aksara Pratama.

Dalman, H. (2015). Keterampilan Menulis. Jakarta: PT. RajaGrafindo Persada.

Finoza, Lamuddin. (2013). Komposisi Bahasa Indonesia. Jakarta: Diksi Insan Mulia.

Prastowo, Andi. (2012). Metode Penelitian Kualitatif Dalam Perspektif Rancangan. Jogjakarta: AR- Ruzz Media.

Sugiyono. (2016). Metode Penelitian Kuantitatif, Kualitiatif, Dan R\&D. Bandung: Alfabeta, CV.

Thoifah, I'anatut. (2015). Statistik Pendidikan dan Metode Penelitian Kuantitatif. Malang: Madani (Kelompok Instrans Publishing), Wisma Kalimetro.

Yunus, Mohammad. (2013). Keterampilan Menulis. Tangerang Selatan: Universitas Terbuka. 